\title{
Pemberdayaan Masyarakat Bidang Kewirausahaan Pengolahan Limbah Buah Rambutan di Desa Keleyan Kabupaten Bangkalan
}

\author{
Diah Wahyuningsih \\ Fakultas Ekonomi dan Bisnis, Universitas Trunojoyo Madura \\ Universitas Trunojoyo Madura \\ E-mail : diah.wahyuningsih@trunojoyo.ac.id
}

DOI: http://dx.doi.org/10.21107/pgd.v5i1.5167

\begin{abstract}
Abstrak
Artikel Diterima : 10 November 2018/ Revisi : 17 Februari 2019/Terbit : 15 April 2019

Kegiatan pengabdian masyarakat ini bertujuan untuk pelatihan kewirausahaan yang berdasarkan potensi yang ada. Kegiatan pemberdayakan masyarakat Desa Keleyan dilakukan dengan metode sosialisasi, pelatihan dan praktek pengolahan limbah rambutan. Hasil kegiatan menunjukkan bahwa pelatihan kewirausahaan berdasarkan potensi unggulan di Desa Kelayan berfokus pada pembentukan pola pikir masyarakat dari pekerja menjadi pencipta pekerjaan. Substansi pelatihan kewirausahaan terkait dengan potensi Desa Keleyan memanfaatkan limbah rambutan. Limbah rambutan yang digunakan adalah biji dan kulit yang bisa diolah menjadi emping biji rambutan Keleyan (EBI BULE), teh kulit rambutan (Teh Kabayan) dan kompos takakura. Selain itu masyarakat juga diperkenalkan pada pentingnya kemasan dan desain label makanan agar menarik minat pembeli. Hasil pelatihan kewirausahaan diharapkan bisa memberikan nilai tambah bagi masyarakat.
\end{abstract}

Kata Kunci : limbah rambutan, kewirausahaan, Desa Keleyan

\section{PENDAHULUAN}

Rambutan (Nephelium laphecium) merupakan tanaman buah hortikultural dengan famili Sapindacaeae. Rambutan termasuk jenis buah khas daerah tropis dan tersebar di seluruh daerah di Indonesia yang dalam bahasa Inggrisnya disebut Hairy Fruit. Rambutan berasal dari Indonesia dan telah menyebar luar di daerah yang beriklim tropis seperti Filipina dan negara-negara Amerika Latin dan ditemukan pula di daratan yang mempunyai iklim sub-tropis. Rambutan dibudidayakan dengan memanfaatkan buah yang mempunyai gizi, zat tepung, sejenis gula yang mudah terlarut dalam air, zat protein dan asam amino, zat lemak, zat enzim-enzim yang esensial dan nonesensial, vitamin dan zat mineral makro, mikro yang menyehatkan keluarga, tetapi ada pula sementara masyarakat yang memanfaatkan sebagai pohon pelindung di pekarangan, sebagai tanaman hias.

Produksi buah rambutan sangat besar dan berpotensi menghasilkan devisa. Produksi rambutan di Indonesia pada tahun 2017 cukup besar yaitu 523.704 ton dan diekspor sebesar 290.885 ton. (BPS, 2017) Direktur Jenderal Hortikultura Kementerian Pertanian (Kementan) menyatakan ekspor rambutan naik $98,3 \%$. Tujuan ekspor rambutan Indonesia antara lain Amerika Serikat, German, Belanda, Perancis, Arab Saudi,
Uni Emirat Arab, Kuwait, Bahrain, Singapura, Qatar, Nederland dan Taiwan.

Desa Keleyan memiliki potensi sumber daya alam yang melimpah yang dimanfaatkan untuk menunjang kebutuhan masyarakat. Desa Keleyan memiliki tekstur tanah debuan dan berwarna merah, biasanya dimanfaatkan warga untuk lahan sawah, ladang dan kebun. Luas tanah sawah irigasi yaitu 50,00 Ha, ladang/tegal seluas 205,00 Ha dan tanah rawa seluas 37,00 Ha. Kegiatan bercocok tanam yang dilakukan masyarakat Desa Keleyan seperti menanam jagung, kacang tanah, rambutan dan nangka. Selain itu, terdapat aliran sungai yang membantu dalam proses irigasi sawah dan pengairan lainnya. Luas sungai sebesar 3 Ha yang dijadikan tempat hidup ikan-ikan. Tambak-tambak ikan dan udang di air tawar dan payau juga banyak dikembangkan oleh masyarakat Desa Keleyan untuk mengoptimalkan potensi desa yang dimiliki.

Masyarakat Desa Keleyan umumnya membudidayakan tanaman pangan sembari beternak hewan peliharaan seperti sapi, kambing, ayam kampung dan itik. Komoditas unggulan Desa Keleyan adalah kacang tanah, jagung, nangka dan rambutan. Berdasarkan data profil Kecamatan luas produksi dan sebaran produk unggulan Desa Keleyan yaitu rambutan sekitar $6,35 \mathrm{~km} 2$ atau sebesar $11,80 \%$ terhadap luas 
Kecamatan Socah. Produktivitas padi sawah di Desa Keleyan sebesar 4,50 ton/Ha dengan hasil produksi 283,50 ton dan luas panen sebesar 63,00 Ha. Produktivitas jagung di Desa Keleyan sebesar 2,94 ton/Ha dengan hasil produksi 795,00 ton dan luas panen sebesar 270,00 Ha. Produktivitas kacang tanah di Desa Keleyan sebesar 3,24 ton/Ha dengan hasil produksi 1.100,00 ton dan luas panen sebesar 340,00 Ha. Angka tersebut menunjukkan kuantitas yang cukup besar sebagai desa penghasil rata-rata komoditas unggulan di Kecamatan Socah.

Rambutan mengandung nutrisi, setiap 100 gram kalori $82 \mathrm{kkl}, 0,25$ miligram besi, 0,343 miligram mangan, 0,08 miligram seng, 8 mikrogram folat, 0,022 miligram riboflavin, 0,013 miligram tiamin dan 0,02 miligram [12] vitamin B6. Juga mengandung sekitar 20,87 gram karbohidrat, 0,9 gram serat makanan, 0,21 gram lemak, 0,65 gram protein, 22 miligram kalsium, 7 miligram magnesium, 9 miligram fosfor, 42 miligram kalium, 11 miligram natrium, 4,9 miligram vitamin $\mathrm{C}, 1,352$ miligram niacin. Menurut Hariana, A. (2006) rambutan mengandung zat besi, kalsium, karbohidrat, fosfor, lemak, protein dan vitamin C. Tidak hanya buahnya, kulit buah rambutan juga mempunyai aktivitas antibakteri terhadap bakteri E.coli dan S.aureus (Yudaningtyas, 2009). Penelitian Anshory (2006) menyebutkan bahwa ekstrak etanol kulit buah rambutan memiliki kemampuan meredam radikal bebas DPPH lebih besar dibandingkan vitamin E. Penelitian Thitilerdecha et al., (2010) menyebutkan bahwa beberapa senyawa fenolik seperti asam ellagat, corilagin dan geranin yang diisolasi dari ekstrak metanol kulit buah rambutan merupakan senyawa yang bertanggungjawab terhadap aktivitas antioksidan. Kulit buah rambutan mengandung flavonoid, tanin dan saponin (Dalimartha, 2005) serta antosianin yang diduga sebagai pigmen yang membuat kulitnya berwarna merah tua (Wijaya et al., 2001).

Biji rambutan mengandung polifenol (Dalimartha, 2005) dan beberapa senyawa golongan flavonoid yang telah berhasil diisolasi dari ekstrak etanol biji rambutan yaitu senyawa flavonol tersubstitusi gula pada posisi 7-O dengan gugus hidroksil pada posisi 3, 5, dan 4; senyawa flavonol tersubstitusi pada 3-O dan 7-O dengan gugus hidroksil pada posisi 5 dan 4; dan senyawa flavonoid tersubstitusi pada 5-O (Asrianti et al., 2006). Berdasarkan penelitian Thitilerdecha et al. (2008), senyawa fenolik yang terdapat dalam ekstrak biji rambutan merupakan senyawa yang berperan dalam aktivitas antioksidan dan antibakteri. Kandungan senyawa fenolik dan flavonoid yang ditemukan pada tanaman dapat beraktivitas sebagai antioksidan (Hernani dan Rahardjo, 2006). Penelitian Maisuthisakul et al. (2006) membuktikan bahwa tingginya senyawa fenolik dan flavonoid dari beberapa tanaman menunjukkan aktivitas antioksidan yang kuat. Penelitian Utami et al. (2005) juga menunjukkan bahwa semakin tinggi kadar senyawa fenolik dan flavonoid maka aktivitas penangkap radikalnya semakin meningkat.

Produksi buah rambutan yang berlimpah di Desa Keleyan, sebagian hasil panen rambutan dikosumsi sendiri dan sebagian langsung dijual ke tengkulak tanpa mengolah menjadi produk yang memiliki nilai jual lebih tinggi dan mempunyai profit oriented. Dengan berlimpahnya hasil panen rambutan berdampak pada limbah yang melimpah yang seharusnya bisa dimanfaatkan. Limbah yang bisa dimanfaatkan tersebut berupa daun, kulit dan biji. Namun kenyataannya, limbah rambutan ini belum dimanfaatkan secara optimal apabila hanya didiamkan dapat menimbulkan dampak negatif. Dampak terseput berupa ketidaknyamanan pada masyarakat, kerusakan lingkungan seperti pencemaran lingkungan baik pada air, tanah maupun udara dan sumber penyebaran berbagai penyakit. Namun limbah rambutan yang diolah bermanfaat bagi masyarakat.

Salah satu program Kelompok KKN 06 UTM di Desa Keleyan adalah pemberdayaan kewirausahaan mengolah limbah rambutan. Pemberdayaan masyarakat ini tujuannya untuk memotivasi dan mengembangkan potensi yang ada di Desa Keleyan sehingga bisa memberikan nilai tambah bagi masyarakat.

\section{METODE}

\section{Lokasi dan Partisipan}

Kegiatan dilakukan di Desa Keleyan, Kecamatan Socah, Kabupaten Bangkalan. Partisipan dalam program adalah ibu rumah tangga di 7 dusun Desa Keleyan.

\section{Bahan dan Alat}

Bahan baku yang digunakan untuk membuat emping biji rambutan Keleyan (EBI BULE) dan teh kulit rambutan (Teh Kabayan) adalah kulit rambutan, biji rambutan, air, penyedap rasa, garam, bawang putih, minyak goreng. Peralatan yang digunakan adalah pisau, baskom, tempayan, talenan, wajan, spatula, pemipih, cobek. Sedangkan bahan baku yang digunakan untuk membuat kompos takakura adalah daun rambutan. 
Peralatan yang digunakan adalah sekop, parang, kardus bekas, kain penutup, keranjang berongga, sampah organik, kompos, bantalan sekam.

\section{Prosedur Kegiatan}

Tahapan pelaksanaan kegiatan sebagai berikut:

1. Tahap persiapan meliputi sosialisasi dan koordinasi program ke pemerintahan desa (Kelurahan, RT dan RW). Tujuan sosialisi adalah untuk mendapatkan dukungan agar pelaksanaan program yang sudah disusun bisa berjalan sesuai rencana dan berjalan dengan baik. Selanjutnya melakukan sosialisasi kepada masyarakat untuk mengikuti program yang akan dilaksanakan agar dapat bermanfaat.

2. Tahap pelaksanaan program dengan melakukan pelatihan dan bimbingan teknis produksi emping biji rambutan Keleyan (EBI BULE), teh kulit rambutan (Teh Kabayan) dan kompos takakura. Bimbingan teknis meliputi teknik produksi, pengelolaan bahan baku dan pengemasan.

\section{HASIL DAN PEMBAHASAN \\ Kondisi Umum Lokasi Kegiatan}

Jumlah penduduk Desa Keleyan yaitu 7441 jiwa dengan jumlah laki-laki sebanyak 3591 jiwa dan jumlah perempuan sebanyak 3850 jiwa. Warga Desa Keleyan pada umumnya bekerja sebagai petani sawah, berladang seperti menanam jagung dan kacang tanah serta beternak seperti sapi, kambing, ayam kampung dan itik. Desa Keleyan terdiri dari 7 dusun yaitu Dusun Bandung Timur, Dusun Bandung Barat, Dusun Keleyan, Dusun Mangga'an, Dusun Rojing, Dusun Pajeten, dan Dusun Langgulang. Kondisi perumahan warga cukup berjauhan antara satu dengan yang lainnya karena disekat oleh ladang atau kebun yang cukup luas namun tetap dapat dijangkau dengan berjalan kaki maupun berkendara (BPS, 2017).

\section{Pembuatan Teh Kulit Rambutan}

Biasanya orang mengkonsumsi buah ini hanya buah bagian daging buahnya saja lalu kulitnya dibuang begitu saja. Kulit rambutan yang dianggap sampah ternyata mempunyai manfaat. Kulit rambutan terkandung flavonoida, buah rambutan yaitu salah satu buah tropis yang dapat kita jumpai dengan gampang. Saat tengah musim, harga nya juga murah. Bahkan juga, untuk yang mempunyai pohonnya sendiri, kita dapat menuai sendiri di kebun. Kulit rambutan juga bermanfaat untuk kita, terlebih untuk obat sebagian penyakit.
Bila sampai kini kita umum buang kulit rambutan sesudah mengonsumsi buahnya. Saat ini, kita dapat memakai kulit rambutan untuk jadikan obat sebagian obat. Mayoritas dari masyarakat Desa Keleyan kebanyakan menanam pohon rambutan di perkebunan. Kurangnya pengetahuan penanganan panen dan pascapanen menyebabkan hasil panen rambutan yang tidak maksimal. Hasil panen yang tidak maksimal ini menyebabkan nilai jual dipasar menurun. Masyarakat kebanyakan menjual hasil panen dalam bentuk mentah dan tidak dikemas semenarik mungkin. Penangan pascapanen sendiri adalah tindakan yang disiapkan atau dilakukan pada tahapan pascapanen agar hasil pertanian siap dan aman digunakan oleh konsumen atau diolah lebih lanjut. Kelompok KKN 06 UTM di Desa Keleyan berinovasi meanfaatkan kulit rambutan menjadi teh.

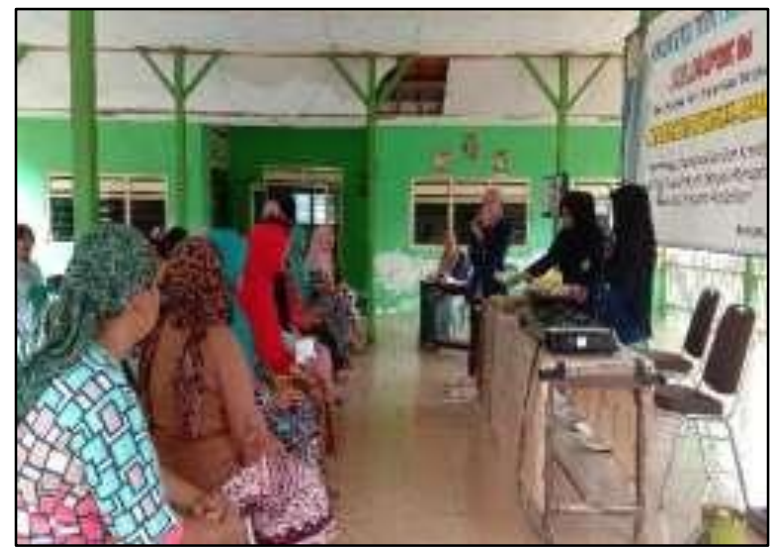

Gambar 1. Sosialisasai Program Pengabdian Masyarakat

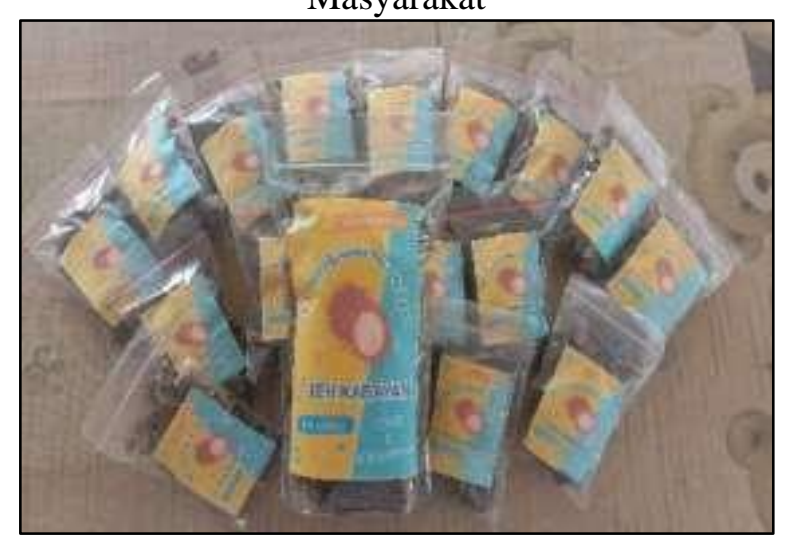

Gambar 2. Produk Teh Kabayan

Teh Kabayan merupakan akronim dari teh kulit rambutan keleyan. Teh kabayan merupakan salah satu program kerja utama kelompok KKN 06 Desa Keleyan. Pelatihan dan bimbingan teknis pembuatan teh kabayan dilaksanakan pada hari sabtu tanggal 19 januari 2019 dilaksanakan di Balai Desa Keleyan tepat pukul 10.00 WIB sampai 11.30 WIB. Pelatihan dan bimbingan 
teknis ini dihadiri oleh semua anggota KKN 06 UTM dan ibu rumah tangga Desa Keleyan. Pelatihan ini berjalan dengan lancar dan warga terlihat antusias dalam mengetahui proses pembuatan teh kabayan. Sebagian ibu-ibu ikut berperan langsung dalam pembuatan teh kabayan yang didemonstrasikan. Teh kabayan memiliki cita rasa yang khas berbeda dari teh pada umumnya, sedikit masam dan manis.

\section{Pembuatan Emping Biji Rambutan}

Menurut analisis proksimat menunjukkan bahwa biji rambutan mengandungi 11,9$14,1 \%$ protein, hampir sama dengan protein jagung yang sekitar $10 \%$, mengandung juga 37,1$38,9 \%$ lemak kasar, 2,8-6,6\% serat kasar pada berat kering. Profil asam amino protein biji rambutan menunjukkan bahwa mutu protein biji adalah baik. Biji rambutan tidak beracun dan mengandung karbohidrat. Kandungan tersebut dapat memenuhi kebutuhan tubuh akan gizi. Biji rambutan juga mengandung lemak polifenol yang cukup tinggi. Komposisi zat-zat kimia dalam biji rambutan tersebut menghasilkan khasiat hipoglemik sehingga dapat digunakan sebagai pengobatan alternatif guna menormalkan kadar gula dalam darah yang cenderung tinggi bagi penderita penyakit diabetes mellitus.

Emping biji rambutan digunakan sebagai bahan utama dalam pembuatan produk dikarenakan mayoritas masyarakat desa keleyan tidak memanfaatkan emping biji rambutan. Emping biji rambutan tidak beracun dan memiliki kandungan karbohidrat, protein, lemak dan vitamin C. Manfaat emping biji rambutan yaitu mencegah penyakit diabetes, mencegah penyakit kencing manis, sebagai anti bakteri yang alami, mencegah penyakit anyang-anyangan, mengatasi sariawan dan sebagai antioksidan. Kurangnya pengetahuan penanganan panen dan pascapanen menyebabkan hasil panen buah rambutan yang tidak maksimal. Penangan pascapanen sendiri adalah tindakan yang disiapkan atau dilakukan pada tahapan pasca panen agar hasil perkebunan siap dan aman digunakan oleh konsumen atau diolah lebih lanjut.

Pengemasan produk dapat meningkatkan mutu dari produk-produk makanan yang memiliki peranan sangat penting untuk memperpanjang umur produk. Kemasan produk makanan ternyata tak bisa dianggap sepele dalam sebuah bisnis. Karena kemasan selain berfungsi mempercantik suatu produk sehingga meningkatkan nilai jual. Sekaligus juga, memberikan keyakinan dan kenyamanan bagi produsen dan konsumen terkait status kehalalan produk pangan tersebut. Ternyata plastik juga mampu mempengaruhi daya simpan atau kadaluwarsa suatu produk. Sehingga tidak boleh sembarangan memilih bahan untuk kemasan produk. Karena jika salah maka produk yang dikemas akan cepat rusak dan membuat kapok pembeli. Kemasan ini cocok untuk makanan ringan seperti emping biji rambutan dan teh kulit rambutan namun tidak cocok untuk cairan. Plastik kemasan zipper ini sangat bening sehingga produk bisa langsung dipamerkan karena dari luar terlihat sangat jelas. Zipper merupakan salah satu kemasan produk makanan yang sangat disukai pelanggan karena bisa dengan mudah dibuka dan ditutup. Sehingga mencegah makanan lempem. Kemasan yang memiliki ketebalan 120 micron ini memiliki material super clear pp.

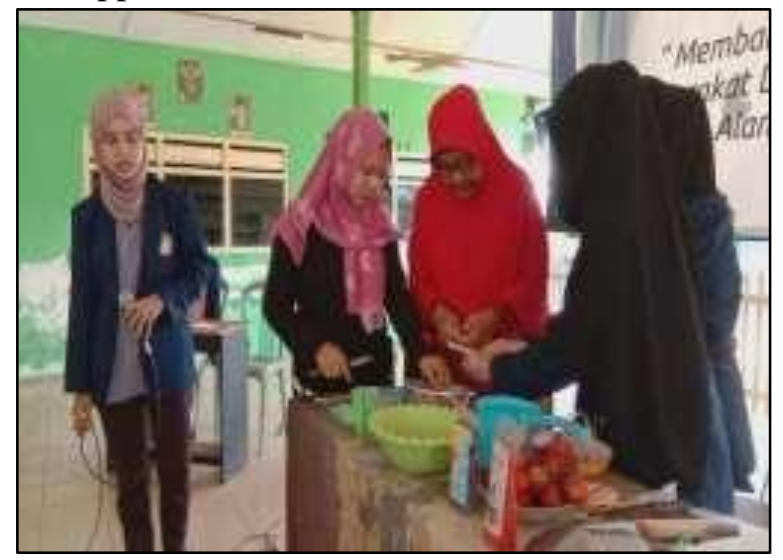

Gambar 3. Pelaksanaan Pelatihan Pengolahan Biji Rambutan oleh Mahasiswa KKN

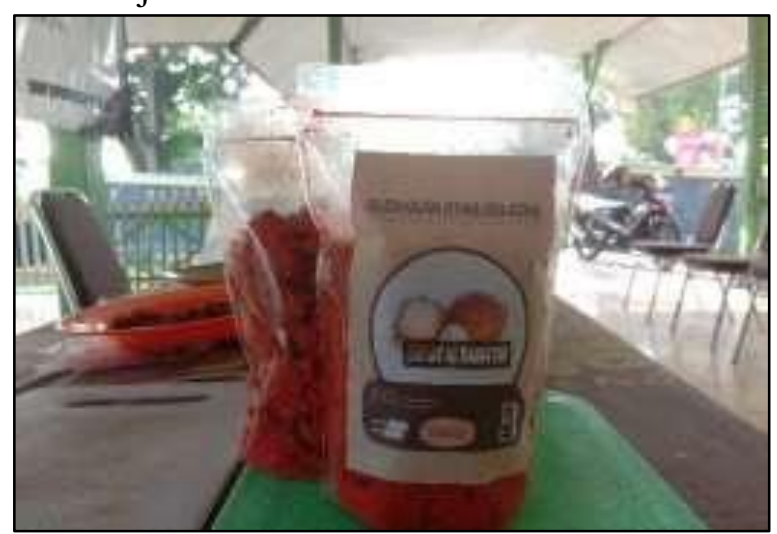

Gambar 4. Emping Biji Rambutan yang Telah Dikemas

\section{Pembuatan Kompos Takakura}

Pembuatan kompos takakura merupakan pemanfaatan teknologi tepat guna dari kelompok KKN 06. Takakura merupakan salah satu metode pengelolaan sampah menjadi kompos. Metode ini menggunakan kardus sebagai tempat untuk proses pengelolahan kompos. Pengomposan ini dapat 
berupa sampah rumah tangga seperti sisa sayuran yang belum basi, sisa nasi, sisa ikan, sisa ayam dan dapat berupa sampah buah yang lunak seperti kulit jeruk, apel, rambutan dan sampah organik lainnya. pupuk kimia.

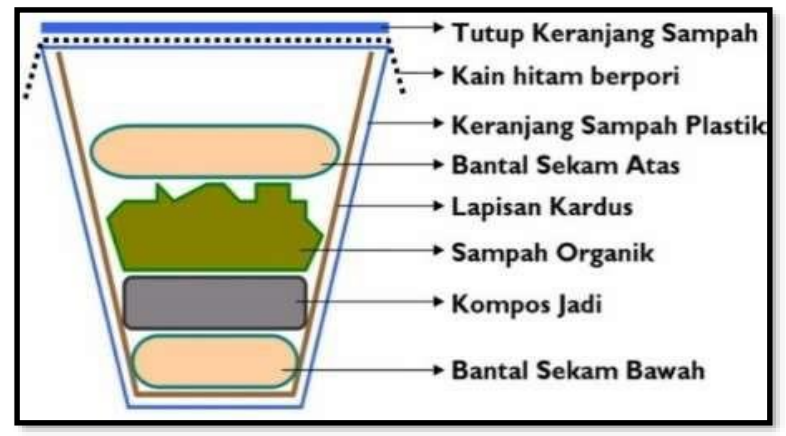

Gambar 5. Konsep Pembuatan Kompos Takakura

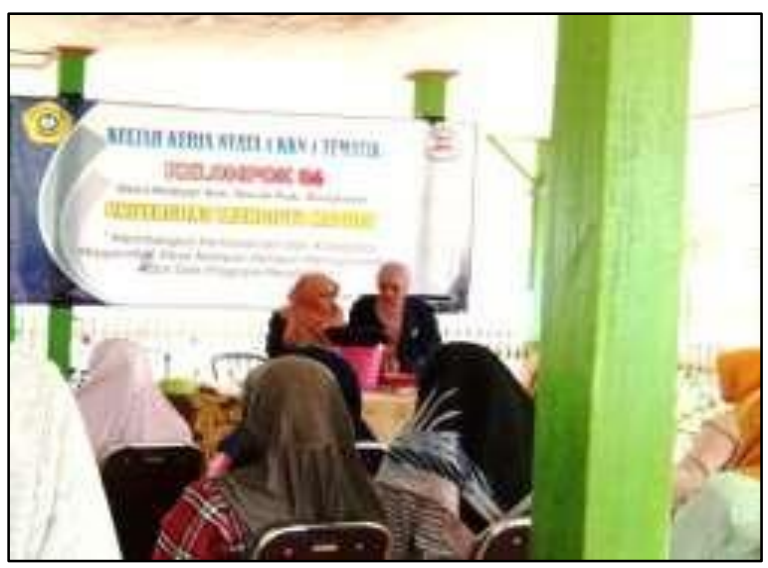

Gambar 6. Pelaksanaan Pelatihan oleh Mahasiswa KKN

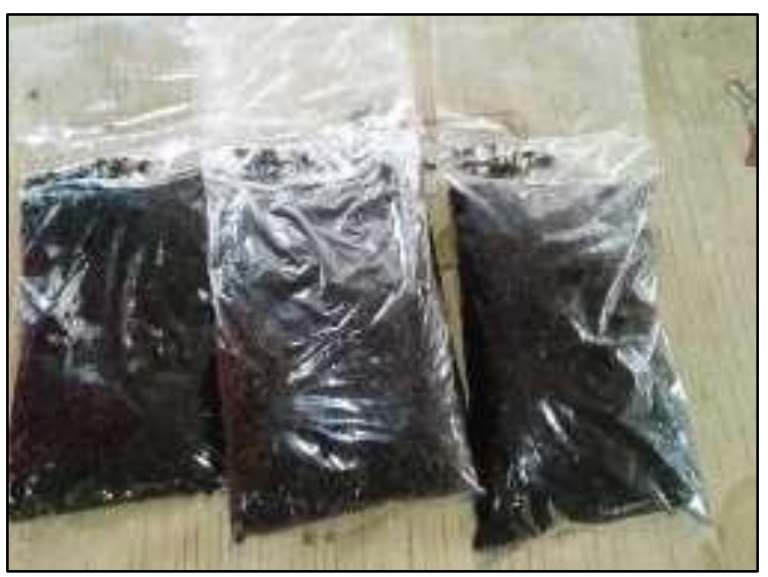

Gambar 7. Hasil Pembuatan Kompos Takakura dari Limbah Kulit Rambutan

Kulit rambutan, sebagaimana kulit buah yang lain, merupakan bagian buah yang tidak dimanfaatkan. Kulit tersebut tidak dikonsumsi dan akan dibuang menjadi sampah. Sebagai bahan organik, kulit rambutan bisa dimanfaatkan menjadi pupuk organic yang dapat digunakan kembali untuk memupuk pohon rambutan maupun tanaman yang lain sehingga lebih subur dan mengurangi dampak negatif dari penggunaan

\section{KESIMPULAN}

Kegiatan pengabdian masyarakat melalui program KKN Tematik Mandiri Desa Keleyan telah melaksanakan program kerja secara teori dan praktek sehingga warga Desa Keleyan dapat terlibat langsung dalam program kerja yang diusulkan sehingga pengembangan potensi Desa Keleyan menjadi lebih kreatif dan produktif. Adapun program yang dilaksanakan adalah memanfaatkan limbah rambutan yaitu biji dan kulit rambutan menjadi olahan makanan emping dan teh. Selain itu limbah rambutan juga bisa dibuat kompos takakura.

\section{DAFTAR PUSTAKA}

Hariana, A. 2006. Tumbuhan Obat dan Khasiatnya. Penebar Swadaya.

Yudaningtyas, A.D.. 2009. Uji Aktivitas Antibakteri Kulit Buah Rambutan (Nephelium lappaceum L.) Terhadap Bakteri Escherichia coli dan Staphylococcus aureus Dengan Metode Bioautografi. Skipsi. Fakultas MIPA Universitas Malang.

Anshory, H., Suparmi, dan Tumimy, A.S. 2006. Aktivitas Antioksidan Kulit Buah Rambutan (Nephelium lappaceum L.) terhadap Penangkapan Radikal Bebas DPPH. Jurnal Ilmiah Farmasi. Vol 3 (1). 9-15 pp.

Asrianti, M., Ruslan, K., dan Nawawi, A. 2006, Telaah Fitokimia Biji Rambutan (Nephelium lappaceum L). Skipsi. Teknik Farmasi. Institut Teknologi Bandung.

BPS. 2017. Statistik Tanaman Buah-buahan dan Sayuran Tahunan Indonesia. Jakarta.

Dalimartha. 2005. Atlas Tumbuhan Obat Indonesia (Jilid 3). Puspa Swara. Jakarta.

Hernani dan Raharjo, M. 2006. Tanaman Berkhasiat Antioksidan. Penebar Swadaya. Jakarta.

Maisuthisakul, P., Pasuk, S., and Ritthiruangdej, P .2006. Relationship Between Antioxidant Properties and Chemical Composition of Some Thai Plants. Journal of Food 
Composition and Analysis. Vol 21. 229$240 \mathrm{pp}$

Thitilerdecha, N., Teerawutgulrag, A., and Kilburn, J.D. 2010. Identification of Major Phenolic Compounds from Nephelium lappaceum $L$. and Their Antioxidant Activities. Molecules. Vol 15. 1453-1464 pp.

Utami, W., Da'i, M., dan Sofiana, Y.R.. 2005.
Aktivitas Penangkap Radikal dengan Metode DPPH serta Penetapan Kandungan Fenol dan Flavonoid dalam Ekstrak Kloroform, Ekstrak Etil Asetat, Ekstrak Etanol Daun Dewandaru (Eugenia uniflora L.). Pharmacon. Vol 6 (1). 5-9 pp.

Wijaya, L.S. 2001. Ekstraksi dan Karakterisasi Pigmen dari Kulit Buah Rambutan (Nephelium lappaceum) Var. Binjai. Biosain. Vol 1 (2). 